\title{
A „TECHNICIZÁLT” TÁJAK JELENTŐSÉGE A FIATAL MÜSZAKI MÉRNÖKJELÖLTEK ÉLETÉBEN
}

\author{
Nagy Valéria - Wang Chao-Tang
}

\begin{abstract}
Absztrakt: A táj hatással van az emberre, azonban az emberi tevékenység hatására a táj is változik/változhat, amely változásnak negatív pszichológiai, élettani hatásai is lehetnek. A kompetenciadús táj egy rendkívül „komplex ékszer” az életünkben, hozzájárul egészségünk megőrzéséhez, tágabb értelemben jóllétünk meghatározója. Jelen közlemény célja annak felmérése, hogy a leendő müszaki mérnökök a hatás-ellenhatás mechanizmusának ismeretében milyen értéket tulajdonítanak a tájnak/tájképnek saját egészségük vonatkozásában, illetőleg milyen attitüd jellemzi őket a kompetenciadús tájak megőrzésének, formálásának folyamatában. E célkitűzés megvalósítása rövid kérdőíves felmérés keretében valósult meg 68 fő egyetemi hallgató véleményének feldolgozásával. A transzdiszciplináris felmérés eredményeként az egészségmegőrzés témakörében a táj/tájkép fogalmához a nyugalom, kikapcsolódás, feltöltődés, sportolás (biciklizés, futás, túrázás, séta) fogalmakat társítják leginkább a válaszadók. Az eredmények alapján megállapítható továbbá, hogy a megkérdezett fiatal felnőttek körében a jelen ,élményvilága” (a „technicizált” tájak vonatkozásában) felértékelődik, ugyanakkor a jövőbeni tájpotenciálnak az egészségre gyakorolt hatása miatt aggódók aránya $\sim 70 \%$-os. Az eredmények azt sugallják, hogy a jövőben továbbra is figyelemmel kell lenni, illetve erösíteni kell a mérnökjelöltekben, hogy a tevékenységük során az technológiai hatáselemzések elvégzése mellett az ökológiai hatáselemzések elvégzését se hanyagolják el a pozitív pszichológiai, élettani hatásokkal bíró tájak kialakítása okán.
\end{abstract}

Abstract: Landscape has an effect on people, however, as a consequence of human activity, landscape changes / might change, which can also have negative psychological and physiological effects, too. Competence-rich landscape is an extremely "complex jewellery" in our lives, contributing to the preservation of our health, in a broader sense, a determinant of our well-being. The aim of this paper is to assess the value that future technical engineers approach to surrounding area/landscape by knowing the action - reaction mechanism in relation to their own health, in addition to their attitude in the process of preserving and shaping competence-rich landscapes. This objective was achieved through a short survey (analysis of the opinions of 68 university students). As a result of the transdisciplinary survey (questionnaire), the concepts of calmness, relaxation, resting, sports (cycling, running, hiking, walking) are most often associated with the definition of landscape/scenery in the topic of health preservation. The results also show that among the young adults surveyed, the present of "world experience" (in terms of "technicalized" landscapes) is appreciated, while the percentage of those worried about the impact of future landscape potential on health is approximately $70 \%$. Based on the results, in the future, it is essential to keep paying attention, as well as to strengthen in engineer candidates that in their course of their works do not neglect ecological impact assessments besides technological impact assessments due to the creation of landscapes with positive psychological and physiological effects.

Kulcsszavak: jóllét, fizikai aktivitás, egészségmegtartás, életminőség, korreláció

Keywords: well-being, physical activity, health-behaviour, quality of life, correlation

\section{Bevezetés}

A boldogság világnapja (március 20.) és a koronavírus okozta korlátozott élethelyzet ihlette azt a kis elemszámú felmérést, amely annak vizsgálatára irányult, hogy a müszaki képzési területen tanulmányokat folytató fiatal felnőttek miként értékelik a táj szerepét egészségmegőrzésükben és hogyan kívánják érvényre juttatni a táj(kép)i (Ghimessy, 1984; Csemez, 1996; Bowen, 2019) potenciált - a táj teljesítőképességét, 
alkalmasságát, teljesítményét, tartamosságát - a mérnöki tevékenységük során annak érdekében, hogy a tájaknak pozitív pszichológiai, élettani hatásai legyenek, ennek eredményeként pedig hozzájáruljanak az emberi életminőséghez, jólléthez.

A jóllét az élet számtalan területével összefüggésben megemlíthető. Álljon itt néhány példa az értelmezéséhez. Az Egészségügyi Világszervezet szerint (WHO, 1986) az egészség a mindennapi élet forrása, és nem az élet célja. Egy pozitív koncepció, amelyben hangsúlyos szerep jut a fizikai képességeknek. Tehát az egészségfejlesztés egy folyamat, amelynek során az embereknek - képességük révén - lehetőségük van arra, hogy fokozzák az egészségük feletti ellenőrzést, és ezáltal javíthassák az egészségüket. Vagyis a teljes fizikai, szellemi és társadalmi jóllét állapotának eléréséhez az egyénnek képesnek kell lennie arra is, hogy megváltoztassa környezetét vagy éppen megbirkózzon azzal. Továbbá a jóllét meghatározója az egyén és a környezete közötti kapcsolat szubjektív megélése, értékelése (Deutsch et al., 2015). Ilyen módon jóllétünk egyik komponense lehet a kompetenciadús táj is: komplex erőforrásként immanens értéke révén pozitív hatással van az erőforrás legfőbb használójára, az emberre. A táj - elsősorban esztétikai hatások révén érvényesülő - teljesítőképességét az ember tevékenységével befolyásolja. Példának okáért mérnöki alkotásokat helyez el a tájban, ilyen ún. „technicizált" tájakat létrehozva. Azonban egészségünk megtartása érdekében egyszerre lehetőségünk és kötelességünk (müszaki mérnökként különösen) az olyan tájak megőrzése, kialakítása, formálása, amely eleget tesz a technológiai funkcióknak is és pszichológiai hatása, spirituális befolyása is előnyös. Ebben a hatás-ellenhatás viszonyban az emberi tevékenység és természet harmóniáját (is) szem elött tartó müszaki mérnöki hajlandóságról nyerhetünk információt a jelen közleményben bemutatott felmérés által.

\section{Anyag és módszer}

A felmérés 68 fó hallgató bevonásával valósult meg egy anonimitáson alapuló kérdőíves megkérdezés formájában. A megkérdezettek a Szegedi Tudományegyetem Mérnöki Kara három kisebb hallgatói csoportjának tagjai (56 fó férfi, 12 fő nő), többségükben 20-22 éves fiatal felnőttek, akik müszaki képzési területen folytatnak tanulmányokat, de néhány tantárgy keretében a müszaki mérnöki tevékenység ökológiai hatásainak értékelésével is kapcsolatba kerültek.

Lévén, hogy az egészség előfeltételei, az egészség alapvető feltételei és forrásai: a béke, a hajlék, az oktatás, az élelem, a jövedelem, a stabil ökoszisztéma, a fenntartható erőforrások, a társadalmi igazságosság és a méltányosság, ezért ezek közül azokat kiválasztva, amelyek a mérnöki tevékenységgel kölcsönviszonyban állnak, teljesíthető a Bevezetésben megfogalmazott célkitüzés. Vagyis, hogy a müszaki mérnökjelöltek milyen értéket tulajdonítanak a tájnak/tájképnek (saját) egészség(ük) vonatkozásában, illetőleg milyen attitüd jellemzi őket a kompetenciadús tájak megőrzésének, formálásának folyamatában.

A felmérés tehát a mérnöki tevékenység által befolyásolt táj/tájkép és az egészségmegtartás kölcsönviszonyában a stabil ökoszisztéma és a fenntartható 
erőforrások érintettek leginkább, az összes többit kielégítőnek és biztosítottnak feltételezve. A kérdések három kisebb modulba rendezettek:

- egyrészt az általános fizikai és mentális egészségi állapot meghatározását célozzák,

- másrészt az egyént körülvevő környezet jellemzésére, illetve az aktivitásra és annak értékelésére (különös tekintettel a szabadidős tevékenységek végzésére), továbbá

- a kompetenciadús „technicizált” tájak kialakítására való hajlandóság és a tájak adta lehetőségek felmérésére is kiterjednek.

Jelen közlemény a vizsgált változók közötti korrelációt is megjeleníti, azonban nem tér ki a szignifikancia elemzésre.

\section{Eredmények}

Az első kérdéscsoportra adott válaszok alapján elmondható, hogy minden megkérdezett hallgató általános fizikai és mentális egészségi állapota kielégítő, melynek háttérében az életkoruk, a családjuk nyújtotta támasz és biztonság, valamint az egészség egyéb előfeltételeinek teljesülése állnak.

Az egyént körülvevő környezet jellemzése során a táj/tájkép fogalomhoz a nyugalom, kikapcsolódás, feltöltődés, sportolás (biciklizés, futás, túrázás, séta) fogalmakat társította a megkérdezett fiatal felnöttek közel 80\%-a. Megfigyelhetö volt továbbá minden válaszadónál, hogy felsorolásukban valamely fizikai aktivitás (sportolási lehetőség) került az első helyre. De a művi elemek túlsúlyával bíró ún. „technicizált" tájakat is kifejezetten pozitívan értékelte $60 \%$. Itt megjegyzendő, hogy érződik a kényelmi szolgáltatásokat biztosító infrastruktúra egyre erősödő hatása az életminőségre. A jelen „élményvilága” (a „technicizált” tájak vonatkozásában) felértékelődik, ugyanakkor a jövőbeni tájpotenciálnak az egészségre gyakorolt hatása miatt aggódók aránya $\sim 70 \%$-os.

A tájkép (a vizuálisan érzékelhető élő és élettelen tájalkotó elemek formákkal és színekkel jellemzett együttese) - mint látvány - a válaszadók 55\%-ánál jelent csupán inspirációt a (mérnöki) tevékenységére. Ez utalhat a társadalom egy részének tájtól való eltávolodására, tekintettel arra, hogy a társadalom egy bizonyos csoportja (születésétől fogva) mesterséges környezetben, mesterséges terekben éli mindennapjait, ami kétségkívül csökkenő tájidentitást eredményez. A megkérdezett fiatal felnőttek körében tehát a müvi tájelemek „természetesek”. Itt azonban figyelembe kell venni azt is, hogy a tájesztétikai szempontok mindig is vitát, problémát generáltak, mert a tájkép megítélése szubjektív és az egyes diszciplínák, társadalmi csoportok képviselői szerint eltérö. A tájkép egyik alapeleme, a látvány mellett minden válaszadónál megjelentek egyéb kompetenciák is, amelyek inkább a táj használatával és kezelésével kapcsolatosak és amelyeket a környezeti ártalmak csökkentésének szükségessége hatására jelenítettek meg. Ilyennek tekinthető pl. a fosszilis tüzelőanyagú energiatermelő létesítmények helyett a megújuló energiák vagy éppen a fásítás a tisztább levegőért. A válaszok mögött húzódik tehát a „mérnökfegyelem” (amelyet erösít a környezeti fenntarthatóság szlogenné válása), mint külső parancs, illetve a belső egyetértés, amely a természeti jelenségek 
megfigyelése és ismerete okán a természet inspirációs erejével azonosítható. Itt hadd legyen szabad megemlíteni, hogy noha a fizikai aktivitás bizonyítottan jótékony hatással bír (pozitív korreláció) a mentális, kognitív teljesítményre (Etnier et al., 2006; Lupien et al., 2007), de a tiszta, nyugodt környezetnek (esetünkben a kompetenciadús tájnak) szintén jótékony hatása van a figyelemre, a feldolgozási sebességre, illetve a kreativitásra (gondoljunk csak arra, hogy költők, festők is legismertebb müveiket a természet „lágy ölén” alkották). Ez a válaszadók felénél megjelent, amely elsősorban a belső értékrendből fakadó azonosulással, illetve magatartási formákkal, szokásokkal magyarázható.

A válaszok alapján megállapítást nyert, hogy a kompetenciadús tájak megőrzésének, formálásának folyamatában megjelenő attitüd összességében elbillen a tanult diszciplína (esetünkben a müszaki tudomány) irányába, de kidomborodik az is, hogy az ember-természet kölcsönviszony megismerése alázatra tanít (a válaszadók 70\%-a gondolja ezt). Lévén, hogy az újdonság- és technológia-vezérelt világunkban egy fiatal felnőtt nehezebben tudja értékelni (és hajlamos inkább alulértékelni) a természet nyújtotta „ingyenes” szolgáltatásokat, ezért is hajlamosabbak ,hibát” elkövetni a tájak kínálta erőforrások (pl. talaj, ásványkincsek, energiahordozók) hasznosítása során.

Az attitüd vizsgálatára irányuló kérdésekre adott válaszok között felfedezhetők „ellentmondásos” válaszok, válaszegyüttesek is, amelyek a mindenkor elérhető és rendelkezésre álló e-információhalmaz mintát adó jellegének tudhatók be. A fiatal felnőttek körében túlzottan értékelt technika, technológia, digitalizáció, mesterséges intelligencia meghatározó, időlegesen háttérbe szorítja az egyéb területeket. Ugyanakkor e válaszok sem elhanyagolandók, mert a nem kiforrott technológiák a korai adaptálók körében hatással bírnak az egészségre, a környezetre, amely iránti aggodalom és/vagy kíváncsiság minden válaszadónál meg is jelenik.

$\mathrm{Az}$ eredmények kiértékelése során figyelemmel kellett lenni arra is, hogy mindennapi életünk természetes velejárója a stressz. E témában említést érdemel Selye János (orvos, vegyész), aki a stressz kutatója volt (Selye, 1956), és a stressz fogalmát a következőképpen definiálta: „A szervezet nem specifikus reakciója minden olyan ingerre, amely kibillenti eredeti egyensúlyi állapotából, és alkalmazkodásra kényszeriti”". Egyébiránt a stressz - mint a terhelő hatások összessége - a latin 'strictus' szóból eredeztethető, melynek jelentése feszes, szoros, korlátok közé szorít.

Visszatérve az eredeti gondolatmenethez, a válaszok is megjelenítették, hogy a müszaki mérnökök cselekvései stresszfaktorként jelentkez(het)nek a tájban, ugyanakkor a kompetenciavesztett táj karakterelemei, illetve maga a tájkép szintén stresszfaktorok (lehetnek) az ember életében az emberi egészséggel összefüggésben. Megjegyzendő, hogy a tájak vonatkozásában a mesterséges rendezettség ökológiai értelemben véve mindig pusztulást takar, habár a válaszok azt mutatták, hogy esztétikai értékük bizonyos mértékig a vizsgált társadalmi csoport számára ennek ellenére is (lehet) pozitív hatású.

A változók közötti összefüggések, kapcsolatok feltárására, illetve a kapcsolatok szorosságának jellemzésére használt egyik méröszám (Karl Pearson nyomán) az ún. 
korrelációs együttható (r) (Lásd: (1)). A korrelációszámítás szimmetrikus kapcsolatot tételez fel két változó $(\mathrm{x}, \mathrm{y})$ között, ahol mindkét változó valószínüségi változónak tekinthető. Tehát nem az egyik változónak a másiktól való függését, „csak” a kapcsolatukat jellemzi.

$$
r=\frac{n \cdot \sum_{i=1}^{n} x_{i} y_{i}-\sum_{i=1}^{n} x_{i} \sum_{i=1}^{n} y_{i}}{\sqrt{\left(n \cdot \sum_{i=1}^{n} x_{i}^{2}-\left(\sum_{i=1}^{n} x_{i}\right)^{2}\right)\left(n \cdot \sum_{i=1}^{n} y_{i}^{2}-\left(\sum_{i=1}^{n} y_{i}\right)^{2}\right)}}=\frac{\sum_{i=1}^{n}\left(x_{i}-\bar{x}\right)\left(y_{i}-\bar{y}\right)}{\sqrt{\sum_{i=1}^{n}\left(x_{i}-\bar{x}\right)^{2} \sum_{i=1}^{n}\left(y_{i}-\bar{y}\right)^{2}}}
$$

A szóródási diagramok elkészítése után a részeredmények korrelációanalízise (Lásd: 1. táblázat) rávilágított arra, hogy a kompetenciavesztett táj, mint stresszfaktor, szignifikáns negatív kapcsolatban (inverz negatív korreláció) áll az egészségi állapottal, tágabb értelemben a jólléttel (mint dinamikus egyensúlyi mutatóval). Eszerint elmondható, hogy minél nagyobb mértékben észleli az egyén a stressz jelenlétét, annál elégedetlenebb az egészségi állapotát illetően. Az egészségi állapotra történő fókuszálás és a mérnöki hajlandóság között pedig markáns pozitív kapcsolat igazolódott.

\begin{tabular}{|c|c|c|c|c|c|}
\hline változók & $\begin{array}{c}\text { egészségi állapot } \\
\text { (tágabb } \\
\text { értelemben a } \\
\text { jóllét) megítélése }\end{array}$ & $\begin{array}{c}\text { egyént } \\
\text { körülvevő } \\
\text { környezet } \\
\text { befolyásoló } \\
\text { hatása }\end{array}$ & $\begin{array}{c}\text { kompetencia- } \\
\text { dús } \\
\text { „technicizált” } \\
\text { táj preferálása }\end{array}$ & $\begin{array}{l}\text { kompetencia- } \\
\text { vesztett táj } \\
\text { (stresszfaktor) } \\
\text { kialakulása }\end{array}$ & $\begin{array}{c}\text { mérnöki } \\
\text { hajlandóság a } \\
\text { tájpotenciál } \\
\text { fokozására }\end{array}$ \\
\hline $\begin{array}{c}\text { egészségi állapot } \\
\text { (tágabb } \\
\text { értelemben a } \\
\text { jóllét) megítélése }\end{array}$ & - & & & & \\
\hline $\begin{array}{c}\text { egyént körülvevö } \\
\text { környezet } \\
\text { befolyásoló } \\
\text { hatása } \\
\end{array}$ & $+0,84$ & - & & & \\
\hline $\begin{array}{l}\text { kompetenciadús } \\
\text { „technicizált" táj } \\
\text { preferálása }\end{array}$ & $+0,79$ & $+0,47$ & - & & \\
\hline $\begin{array}{l}\text { kompetencia- } \\
\text { vesztett táj } \\
\text { (stresszfaktor) } \\
\text { kialakulása }\end{array}$ & $-0,66$ & $-0,31$ & $-0,18$ & - & \\
\hline $\begin{array}{c}\text { mérnöki } \\
\text { hajlandóság a } \\
\text { tájpotenciál } \\
\text { fokozására }\end{array}$ & $+0,71$ & $+0,49$ & $+0,68$ & $-0,59$ & - \\
\hline
\end{tabular}

Forrás: A szerzők saját szerkesztése.

Tekintettel arra, hogy a müszaki fejlesztés, ilyen módon a „technicizált” tájak megjelenésének velejárói (lehetnek) a szennyezőanyagok, a zaj, a rezgés, a fény, 
illetve egyéb - még ismeretlen - környezeti ártalmak megjelenése is, ezért a változók bővítése (részekre bontása), továbbá a korreláció mögötti ok-okozati összefüggések feltárása is indokolt lehet.

\section{Megvitatás}

A táj(egység), illetőleg a tájkép a tájhasználat változásainak hatására alakul, formálódik, ahogyan gróf Teleki Pál (Teleki, 1937) már korábban utalt arra a kölcsönviszonyra, amelyben az emberi tevékenység hatására változik a táj, ugyanakkor a táj is hatással van az emberre: „A táj az emberi életet is formálja.” A müszaki mérnöki alkotó tevékenység során létrejövő objektumoknak tájtípusonként eltérő hatásai lehetnek, azonban a technológiai hatáselemzés révén folyamatos monitorozás válik lehetővé, egy változó környezetben újra és újra értékelhető az emberi cselekedetek (mérnöki tevékenység) hatása, és biztosítható, hogy az emberek életére (közvetetten egészségére) hosszú távon pozitív hatással bíró mérnöki alkotások, müvi tájelemek valósuljanak meg.

A megkérdezettek fontosnak tartják a kompetenciadús „technicizált” tájak kialakítását (a hajlandóság tetten érhető), de a tanult diszciplína prioritást élvez $(80 \%)$. Persze erre proaktív müszaki mérnöki viselkedés esetén is legfeljebb esély van, hiszen „a táj ... jellege természeti tényezök és/vagy emberi tevékenységek hatása és kölcsönhatása eredményeként alakult ki" (Tájstratégia 2017-2026). És ne feledkezzünk meg arról a fizikai alapvetésünkről sem, amelyet energiaminimumra való törekvés elveként jegyzünk, nevezetesen, hogy a természetben minden rendszer a lehető legstabilabb (legkisebb energiájú) állapot elérésére törekszik. Ehhez kapcsolódóan pedig kiemelt szerepe van a természeti értékek és érdekek elfogadásának, amely során a társadalmi-gazdasági folyamatok hosszútávon összhangban vannak a természeti rendszerekkel (Kis-Szekeresné, 2010).

A pozitív élettani hatásokkal bíró tájak/tájegységek kialakításának egyik feltétele tehát mindenkor a konstruktív cselekvésekben bővelkedő emberi magatartás, amely harmóniát eredményez. Ilyen módon előre vetül azoknak a (fiatal) müszaki mérnököknek a szerepe, akik munkájuk során - fejlett absztrakciós képességeiknek köszönhetően - alázattal viseltetnek az egészségmegőrzés iránt (is) és transzdiszciplináris párbeszédet kezdeményeznek a stabil ökoszisztéma és az erőforrások fenntartása érdekében. Ez utóbbi attitüd a kérdőíves felmérés szerint egyértelmüen jelen van a válaszadó fiatal felnőttek körében. Mindegyikük elkötelezett a csoportmunka és a csoporton belüli hatékony kommunikáció iránt.

\section{Következtetések, kitekintés}

A fiatal müszaki mérnökökkel szemben elvárás, hogy legyen élet a tájban, lévén hogy a mindenkori társadalmi-gazdasági adottságokat tükröző táj sokféle szükségletet elégít(het) ki, mindemellett egészségünkre is hatással van. A kérdöíves felmérés (rész)eredményei rámutattak arra, hogy a leendő müszaki mérnökök számára a mủvi tájelemek természetesek. Ilyen módon a „technicizált" tájak megítélése pozitív (60\%-os arány), ugyanakkor az alkotó tevékenységük hatására 
átalakuló táj/tájkép, illetve a megváltozó (csökkenő) tájpotenciál vonatkozásában az egészségre gyakorolt negatív hatás miatti aggódás is jelentős ( $70 \%$-os részarány). Éppen ezért hajlandóságot mutatnak együttmüködésre a negatív hatás mértékének csökkentése érdekében, amelyet néhány változó közötti jelentős és markáns kapcsolat igazol. Ezzel összefüggésben alapvető feladataiknak tekinthető, hogy tevékenységük során lehetőség szerint növeljék a biológiailag aktív felületek arányát és/vagy csökkentsék a biológiailag inaktív felületek arányát, illetve művi tájelemek tájba illesztése során minden esetben szükséges az okozandó tájterhelés meghatározása, melynek része az ökológiai hatáselemzés. (Ez utóbbi alatt értendő azoknak a terhelő hatásoknak a meghatározása, amelyekkel a tájat terhelve, azok szintén terhelésként visszahatnak az emberre.) Motiváló gondolatként eszünkbe juthat a „Fac cotidie aliquantum boni!” latin mondás, amely értékvezérelt magatartást sejtet. Végső soron tehát egy olyan együttmüködő ember-természet kapcsolat kialakítása a cél, amelyben a technológia komplementer, támogató funkcióval bír. E témakörben a helyzetfeltárás a jövőben nagyobb elemszámú mintákon elvégzett felmérésekkel eszközölhető, illetve a keresztmetszeti felmérések metaanalízisei szolgálnak mélyebb, részletesebb információval.

\section{Irodalomjegyzék}

Bowen B. (2019): Glossary of Landscape. Ross NW Watergardens, Portland. <https://www.rossnwwatergardens.com/portland-landscaping-blog/glossary-of-landscapedesign-terms> (2020.03.20.)

Csemez A. (1996): Tájtervezés - tájrendezés. Tankönyvtár, Budapest. 461 p. $<$ https://regi.tankonyvtar.hu/hu> (2020.03.20.)

Deutsch Sz., Fejes E., Kun Á., Medvés D. (2015): A jóllétet meghatározó tényezők vizsgálata egészségügyi szakdolgozók körében. Alkalmazott Pszichológia, 15 (2):49-71.

Etnier J. L., Nowell P. M., Landers D. M. (2006): A meta-regression to examine the relationship between aerobic fitness and cognitive performance. Brain Research Review, 52:119-130.

Ghimessy L. (1984): Tájpotenciál. Mezőgazdasági Könyvkiadó Vállalat, Budapest. 348 p.

Kis K., Szekeresné K. R. (2010): Fenntartható földhasználat jelene és lehetőségei a hódmezővásárhelyi kistérségben. Tájökológiai Lapok, 8(3):421-436.

Lupien S. J., Maheu F., Tu M., Fiocco A., Schramek T. E. (2007): The Effects of Stress and Stress Hormones on Human Cognition: Implications for the Field of Brain and Cognition. Brain and Cognition, 65(3):209-237. https://doi.org/10.1016/j.bandc.2007.02.007

Selye H. (1956): The Stress of Life. McGraw-Hill Book Company, New York

Teleki P. (1937): A tájfogalom jelentőségéröl. Budapesti Szemle, 1937. nov.

Nemzeti Tájstratégia (2017-2026). Földművelésügyi Minisztérium, Nemzeti Parki és Tájvédelmi Főosztály koordinálásával, Budapest;

<https://www.kormany.hu/download/c/ff/f0000/Nemzeti\%20T\%C3\%A1jstrat\%C3\%A9gia_20

17-2026.pdf\#\%21DocumentBrowse> (2020.03.20.)

World Health Organization (WHO) (1986) The Ottawa Charter for Health Promotion. The First International Conference on Health Promotion. Ottawa (Canada). 